\title{
Environmental and Physiological Effects on Cuticle Cracking in Tomato
}

\author{
Cheryld L. Whaley Emmons and John W. Scott \\ Gulf Coast Research and Education Center, University of Florida, Institute of Food and Agricultural \\ Sciences, 5007 60th Street East, Bradenton, FL 34203-9324
}

\begin{abstract}
ADDITIONAL INDEX wORDS. disorder, rainfall, ripening, yield
Abstract. Tomato (Lycopersicon esculentum Mill.) cultivars and breeding lines were evaluated in the field for incidence and severity of cuticle cracking $(C C)$ over four spring seasons at Bradenton, Fla. Resistant and susceptible genotypes were identified and easily distinguished by incidence of $\mathrm{CC}$. When studied over 2 years, the amount of rain during the entire 14 days before harvest was more highly correlated with $\mathrm{CC}$ incidence than the amount of rain during the entire growing season or during 1 to 7 or 8 to 14 days before harvest. Attempts to induce $\mathrm{CC}$ by pruning leaves or fruit from plants were not successful. The incidence of $\mathrm{CC}$ was significantly higher for fruit from unstaked plants (39\%) compared to fruit on staked plants $(10 \%)$. Fruit exposed to direct sunlight, from plants that were staked and not pruned, had significantly greater incidence of $\mathrm{CC}(49 \%)$ than fruit protected by leaf cover $(20 \%)$. Of 218 fruit monitored for affect of developmental stage on occurrence of $\mathrm{CC}, 62$ developed $\mathrm{CC}$. Of these $2 \%, 61 \%, 27 \%$, and $10 \%$ first exhibited $\mathrm{CC}$ at immature-green, mature-green, breaker, and red stages, respectively. For $58 \%$ of fruit with $\mathrm{CC}$, no increase in $\mathrm{CC}$ severity was observed as the fruit ripened. Increases in $\mathrm{CC}$ severity were observed more often between mature-green and breaker than between breaker and table-ripe stages of ripening.
\end{abstract}

Cuticle cracking (CC), a disorder in tomatoes (Lycopersicon esculentum) grown under field and greenhouse conditions, causes a degradation of appearance and reduction of shelf life (Hayman, 1987). The disorder is characterized by hair-like cracks in the cuticle, covering all or portions of the fruit's calyx end, that may extend down the sides of the fruit (Hayman, 1987; Young, 1947). In severe cases, these cracks penetrate to the epidermal wall and form lenticel-like lesions; the tomato produces suberin as a repair mechanism (Faust and Shear, 1972; Tukey, 1959). Other names for $\mathrm{CC}$ are rain check, russeting, crazing, swell cracking, shrink cracking, hair cracking, and cuticle blotch.

Economic losses due to $\mathrm{CC}$ are greater in growing regions prone to rainy weather, especially when fruit are picked at the vine-ripe (fruit with some red color) stage. These fruit have more exposure to the elements than those picked at the mature-green (MG) stage. Extended-shelf-life (ESL) cultivars, which are picked at the vineripe stage, are now widely grown in Mexico. One major constraint for growing ESL cultivars in the eastern United States is CC and other types of cracking that occur more in vine-ripe harvests than in cultivars harvested at the MG stage. Fruit with severe $\mathrm{CC}$ are removed during grading and packing, while fruit with limited $\mathrm{CC}$ may get packed. The latter have decreased shelf life and may harbor postharvest pathogens, possibly resulting in decay of the entire shipment.

Little is known about what factors contribute to resistance or susceptibility to $\mathrm{CC}$, but some information is available concerning the physiological and anatomical factors that increase the occurrence of CC and other types of cracking (radial and concentric) in tomatoes. All types of cracking occur more frequently in tomatoes after periods of high rainfall (Reynard, 1951; Young, 1947) or irrigation (Vincent and Malenaar, 1951). Tomatoes have been reported to be more susceptible to CC at the MG stage (Young, 1947) or 2 to 3 weeks before the breaker (BR) stage (den Outer and van Veenendaal, 1987) than at the immature-green (IG) or table-ripe (TR) stages.

Received for publication 10 Mar. 1997 Accepted for publication 9 July 1997. Florida Agricultural Experiment Station journal series no. R-05439. The cost of publishing this paper was defrayed in part by the payment of page charges. Under postal regulations, this paper therefore must be hereby marked advertisement solely to indicate this fact.
Ehret et al. (1993) and Frazier (1936) indicated that increased cracking was related to pruning vegetative tissue and exposure of fruit to the elements. Exposure to sunlight may have changed the polymerization of cuticular waxes, which made apples more susceptible to cracking (Vries, 1970). Whether this is a factor in $\mathrm{CC}$ in tomatoes is not known. Without staking, more fruit are exposed to direct sunlight and higher fruit temperatures may potentially occur. Fruit pruning, resulting in fewer fruit developing for harvest, increased CC in tomato (Ehret et al., 1993). This may be explained by increased water flow to the remaining fruit.

In this study, the effects of rainfall, staking plants, exposure of fruit to the atmosphere, and pruning fruit and vegetative tissue were evaluated to estimate their individual importance to the induction of $\mathrm{CC}$ in resistant and susceptible tomato cultigens (cultivars and breeding lines) (Soule, 1985; Wehner et al., 1996). The stage of fruit maturity when CC incidence occurred was also evaluated.

\section{Materials and Methods}

Each cultigen (Table 1) was seeded in a greenhouse in Black Beauty spent coal (Reed Minerals Div., Highland, Ind.) medium and transplanted after 2 weeks into Todd planter flats $\left(3.8-\mathrm{cm}^{3}\right.$ cell size) (Speedling, Sun City, Fla.) containing a 1 peat: 1 vermiculite mixture. Cultigens used in most of the experiments represented an array of reactions to $\mathrm{CC}$. Only susceptible cultigens were used in the fruit-exposure and developmental-stage experiments. Beds 20 $\mathrm{cm}$ high and $81 \mathrm{~cm}$ wide on $152-\mathrm{cm}$ centers were formed of EauGallie fine sand and fumigated 2 weeks before transplanting with $67 \%$ methyl bromide : $33 \%$ chloropicrin at $239 \mathrm{~kg} \cdot \mathrm{ha}^{-1}$. Beds were then covered with black polyethylene mulch. Six-week-old seedlings were transplanted in the field at the Gulf Coast Research and Education Center, Bradenton, Fla., spaced $46 \mathrm{~cm}$ apart within plots. Plots were spaced $91 \mathrm{~cm}$ apart in rows, with $152 \mathrm{~cm}$ between rows. Recommended fertilizer and insecticide programs were followed (Hochmuth et al., 1989). Plants were staked individually (1995 and 1996) or as plots (1992 and 1994), unless otherwise indicated, and irrigated by continuous seepage from ditches adjacent to the experimental beds.

Pruning. In 1992, plants from eleven cultigens (Table 1) were 
transplanted into the field on $6 \mathrm{Mar}$. in a split-plot design with four blocks. Each block consisted of eleven plots randomly arranged in six rows, with five to six plants of a cultigen per plot. One plant per plot served as a control, while three others were subjected to one of the following three treatments: exposed, limited, and limited and exposed. In the exposed treatment, three trusses of fruit with at least five IG fruit were exposed to direct sunlight by trimming only those leaves blocking direct sunlight. The limited treatment involved trimming fruit from three trusses to three per truss. The limited and exposed treatment was a combination of the above two treatments. Pruning was done 2 weeks before the oldest fruit in the trusses reached MG. MG and riper fruit were harvested on 5 June from three trusses per plant, and affected fruit were rated for $\mathrm{CC}$ severity. Three trusses with at least five fruit protected by leaf cover were harvested from each control plant.

RainfaLL. In 1994 and 1995, plants from five cultigens, ranging from resistant to susceptible to $\mathrm{CC}$ (Table 1), were transplanted on 8 Mar. in a randomized complete-block design with four blocks and eight plants per plot. In 1994, MG and riper fruit were harvested from all plants per plot on 6 June before seasonal rains, 13 June after moderate rain $(16.4 \mathrm{~cm})$, and 20 June after a significant amount of rainfall $(29.7 \mathrm{~cm})$ (Table 2). In 1995, MG and riper fruit were harvested on an individual plant basis between 30 May and 5 June before seasonal rains and between 12 and 16 June after a significant amount of rainfall $(33.1 \mathrm{~cm})$ (Table 2).

Staking. Plants from three cultigens, two susceptible and one resistant to CC (Table 1), were transplanted on 19 Mar. 1996 in a split-plot design. Four replicates were grown in which duplicate plots (subplots) of eight plants per cultigen (main plot) were planted adjacent to each other in the same row. Plants in one plot were not staked, whereas plants in the other plot were staked and tied. BR and TR fruit were harvested and discarded due to a lack of $\mathrm{CC}$ on 10 June. MG and riper fruit were harvested on 18 June, and $\mathrm{CC}$ incidence and severity were determined.

Fruit EXPOSURE. In 1996, 'Suncoast' (chosen for its suscepti-

Table 1. Cultigens used in cuticle cracking experiments.

\begin{tabular}{|c|c|c|c|}
\hline Year & Experiment & $\begin{array}{r}\text { Cutic } \\
\mathrm{re}\end{array}$ & $\begin{array}{l}\text { cle cracking } \\
\text { eaction }{ }^{2}\end{array}$ \\
\hline \multirow{11}{*}{1992} & \multirow[t]{11}{*}{ Leaf and fruit pruning } & Campbell 28 & $\mathbf{R}$ \\
\hline & & Freshmarket 9 & $\mathrm{R}$ \\
\hline & & Solar Set & MR \\
\hline & & Suncoast & $\mathrm{S}$ \\
\hline & & NC50-7 & $S$ \\
\hline & & Fla. 7171 & $\mathbf{R}$ \\
\hline & & Fla. $7236 \times$ CL59 $15 \mathrm{~F}_{3}$ & MR \\
\hline & & Fla. 7060 & MR \\
\hline & & Fla. 7232B X Fla. $7321 \mathrm{~F}_{4}$ & $7 \mathrm{R}$ \\
\hline & & Fla. 7497 & $\mathrm{R}$ \\
\hline & & Fla. 7181 & $S$ \\
\hline \multirow[t]{5}{*}{$1994-95$} & \multirow[t]{5}{*}{ Rainfall } & Campbell 28 & $\mathrm{R}$ \\
\hline & & Freshmarket 9 & $\mathrm{R}$ \\
\hline & & Suncoast & $S$ \\
\hline & & Fla. 7497 & $\mathbf{R}$ \\
\hline & & Fla. 7181 & $S$ \\
\hline \multirow[t]{5}{*}{1996} & \multirow[t]{3}{*}{ Staking } & Suncoast & $S$ \\
\hline & & Fla. 7497 & $\mathbf{R}$ \\
\hline & & Fla. 7181 & $S$ \\
\hline & Sunlight exposure & Suncoast & $S$ \\
\hline & Developmental stage & Fla. 7181 & $S$ \\
\hline
\end{tabular}

${ }^{\mathrm{x}} \mathrm{R}=$ highly resistant, $\mathrm{MR}=$ moderately resistant, $\mathrm{S}=$ susceptible. Ratings based on 1992 field experiments at Bradenton, Fla. (Table 2). bility to CC) plants were transplanted on $19 \mathrm{Mar}$. in a randomized complete-block design with four blocks and eight plants per plot. BR and TR fruit were harvested on 10 June and discarded since there was no CC. MG and riper fruit were harvested on 17 June. Between 10 June and 17 June, fruit nearing maturity that were growing with full exposure to the weather were tagged. At the second harvest, occurrence of $\mathrm{CC}$ was determined for exposed and unexposed fruit.

DEVELOPMENTAL STAGE OF CC OCCURRENCE. Plants of Fla. 7181 (chosen for its susceptibility to $\mathrm{CC}$ ) were transplanted into the field on 19 Mar. 1996 in a randomized complete-block design with four blocks and eight plants per plot. IG fruit showing no CC (218) were tagged and monitored twice weekly for developmental stage (IG, MG, BR, TR) of occurrence and severity of CC as they matured to the TR stage.

Data ANALYSIS. For each of the above experiments, the incidence of CC was calculated on a per plant $(1992,1995$, and 1996) or per block (1994) basis. Severity was determined using a scale from 1 to 10 based on the proportion of surface area covered by visible cuticle cracking (Fig. 1). The data were transformed with the square root function to improve homogeneity of the variances (Zar, 1984). Analyses of variance and mean separations for incidence and severity of $\mathrm{CC}$ were analyzed for cultigen, block, and treatment effects as well as all interaction effects using the appropriate procedures of the Statistical Analysis System (SAS Institute, Cary, N.C.).

\section{Results}

Pruning. Removal of leaves, fruit, or both did not significantly affect incidence or severity of $\mathrm{CC}$. However, cultigen effects were significant $(p<0.001)$ for incidence and severity. Cultigens ranged in CC incidence from $0.7 \%$ for Fla. 7497 to $28.2 \%$ for Fla. 7181 (Table 3). Severity ranged from 1.8 for breeding line Fla. 7232B x Fla. $7321 \mathrm{~F}_{4}$ to 6.0 for Fla. 7497. The high incidence of severity rating for Fla. 7497 was based on only one affected fruit, which could account for the significant cultigen effect. All other cultigens fell into a range from 2.2 to 3.0 in severity.

RaINFALL. Rainfall for the 1994 and 1995 harvests, incidence, and severity of $\mathrm{CC}$ for the five cultigens tested are presented in Table 2. In both years, incidence of $\mathrm{CC}$ increased with each harvest. Severity for 1994 harvest 1 was based on a low number of affected fruit ( $<10$ for most cultigens tested) and was considered to be an unreliable estimate of CC. When 1994 harvest 1 data were removed from the analysis, severity of affected fruit increased with each harvest during the 2 years of the study.

The harvests may be ranked from low to high conditions for CC induction according to the incidence of CC. Incidence of $\mathrm{CC}$ for 1994 harvest 1 was not significantly different from 1995 harvest 1 . The 1994 harvest 2 had a higher incidence of CC than 1994 harvest 1 and 1995 harvest 1, but less than 1994 harvest 3. Incidence of CC for 1995 harvest 2 and 1994 harvest 3 were not significantly different from each other, but were significantly greater than 1994 harvest 2 (Table 3$)(p \leq 0.05)$. Ranking of harvests by severity of $\mathrm{CC}$ from low to high is as follows: 1994 harvest 2,1995 harvest 1 , 1994 harvest 3 , and 1995 harvest $2(p \leq 0.05)$. The 1995 harvest 1 severity was inflated (3.2) due to the mean of 'Freshmarket 9' (5.3). Severity of CC in 'Freshmarket 9' for three previous growing seasons had ranged from 2.0 to 3.0, making the high rating out of the normal range for this cultigen. Removing this cultigen from analysis brings the mean of 1995 harvest 1 to 1.2 and alters the ranking of harvests from low to high to 1995 harvest 1, 1994 harvest 2, 1994 harvest 3, and 1995 harvest 2. 


\begin{tabular}{|c|c|c|c|c|c|}
\hline \multirow[b]{3}{*}{ Interval before harvest } & \multicolumn{3}{|c|}{1994 Harvest } & \multicolumn{2}{|c|}{1995 Harvest } \\
\hline & 1 & 2 & 3 & 1 & 2 \\
\hline & (6 June) & (13 June) & (20 June) & (30 May) & (12 June) \\
\hline & \multicolumn{5}{|c|}{ Rainfall $^{\mathbf{z}}$} \\
\hline From transplanting & $11.0(14)$ & $16.4(17)$ & $29.7(23)$ & $18.8(15)$ & $33.1(22)$ \\
\hline $14 \mathrm{~d}$ & $1.6(2)$ & $7.0(5)$ & $18.8(9)$ & $3.8(3)$ & $14.3(9)$ \\
\hline 8 to $14 \mathrm{~d}$ & $0.0(0)$ & $1.6(2)$ & $5.5(3)$ & $0.6(1)$ & $11.5(6)$ \\
\hline \multirow[t]{2}{*}{$7 \mathrm{~d}$} & $1.6(2)$ & $5.4(3)$ & $13.3(6)$ & $3.2(2)$ & $2.8(3)$ \\
\hline & \multicolumn{5}{|c|}{ Cuticle cracking } \\
\hline Incidence $^{y}$ & $4.9 c^{x}$ & $24.0 \mathrm{~b}$ & $34.1 \mathrm{a}$ & $4.2 \mathrm{c}$ & $26.3 \mathrm{ab}$ \\
\hline Severity $^{\mathrm{w}}$ & $4.1 \mathrm{~b}^{\mathrm{v}}$ & $2.8 \mathrm{c}$ & $3.4 \mathrm{~b}$ & $1.2 \mathrm{~d}^{\mathrm{u}}$ & $4.9 \mathrm{a}$ \\
\hline
\end{tabular}

${ }^{\mathrm{z}}$ Amount in $\mathrm{cm}$ followed by the number of rainfall events in parenthesis.

yPercentage of fruit affected over all cultigens.

'Mean separation in rows by Duncan's multiple range test at $P \leq 0.05$. Data were transformed to square roots before analysis.

${ }^{w}$ Mean for all affected fruit.

${ }^{v}$ Mean is based on $<10$ affected fruit for 4 of 5 cultigens.

"Freshmarket 9 data not included.

Amounts $(\mathrm{cm})$ and events of rainfall 14 to $8 \mathrm{~d}$ to harvest and during the $7 \mathrm{~d}$ before harvest were not significantly correlated to incidence or severity of CC (Table 4). Amount of rainfall from planting to harvest was not significantly correlated with incidence or severity of CC. However, rainfall amounts and frequency within 2 weeks before harvest and number of rainfall events from planting to harvest were correlated to $\mathrm{CC}$ incidence, but not severity. Severity of affected fruit was not correlated to rainfall during any of the time periods tested.

STAKING. The incidence of CC in plants not staked was significantly higher than that of plants that were staked for each of the three cultigens tested (Table 5). On the average, fruit on nonstaked plants had nearly four times as much CC incidence as fruit on staked plants.

Fruit EXPosure. Fruit exposed to the elements had a significantly higher $(P \leq 0.05)$ incidence of $\mathrm{CC}$ than fruit that developed under leaf cover (protected). Almost half (49.1\%) of exposed fruit had CC, whereas $19.7 \%$ of protected fruit had CC.

DeVELOPMENTAL STAGE OF CC OCCURRENCE. $\mathrm{CC}$ first occurred at the MG stage for $61 \%$ of the fruit with CC, whereas $27 \%, 10 \%$, and $2 \%$ occurred at BR, TR, and IG stages, respectively (Table 6). Of fruit with CC, $58 \%$ showed no increase of severity as the fruit ripened on the vine. Increases in CC severity by 1, 2, 3, 4, and 5 points (Fig. 1) occurred in $15.0 \%, 10.5 \%$, $10.5 \%, 1.3 \%$, and $4.6 \%$ of the fruit with CC, respectively. An increase in severity of 1 or more points occurred between $\mathrm{MG}$ and $\mathrm{BR}$ in $73 \%$ of the fruit with CC at MG, whereas $22 \%$

Fig. 1. Cuticle cracking severity rating scale. Fruit have ratings from 0 to 10 moving top to bottom and left to right. Ratings are as follows: 0) glossy, no cracks; 1) dull, hair-like cracks, no lesions visible; 2 ) $\leq 12.5 \%$ of shoulder with lesions; 3 ) $>12.5 \% \leq 25 \%$ of shoulder with lesions; 4) $>25 \% \leq 50 \%$ of shoulder with lesions; 5) $>50 \% \leq 75 \%$ of shoulder with lesions; 6 ) $>75 \% \leq$ $87.5 \%$ of shoulder with lesions; 7) $>87.5 \%<100 \%$ of shoulder with lesions; 8 ) $100 \%$ of shoulder with lesions; 9) lesions extend beyond the shoulder; and 10) fruit totally covered with lesions. of the fruit with CC at BR showed an increase of severity between BR and TR (Table 7).

\section{Discussion}

Young (1947) reported a positive relationship between the incidence of CC and rainfall, although the relationship was not directly tested. Reynard (1951) showed that the incidence of radial cracking in tomatoes was related to the number of days of rain before harvest, but not to the amount of rain. The results of this study indicate that the amount of rain and number of rain events

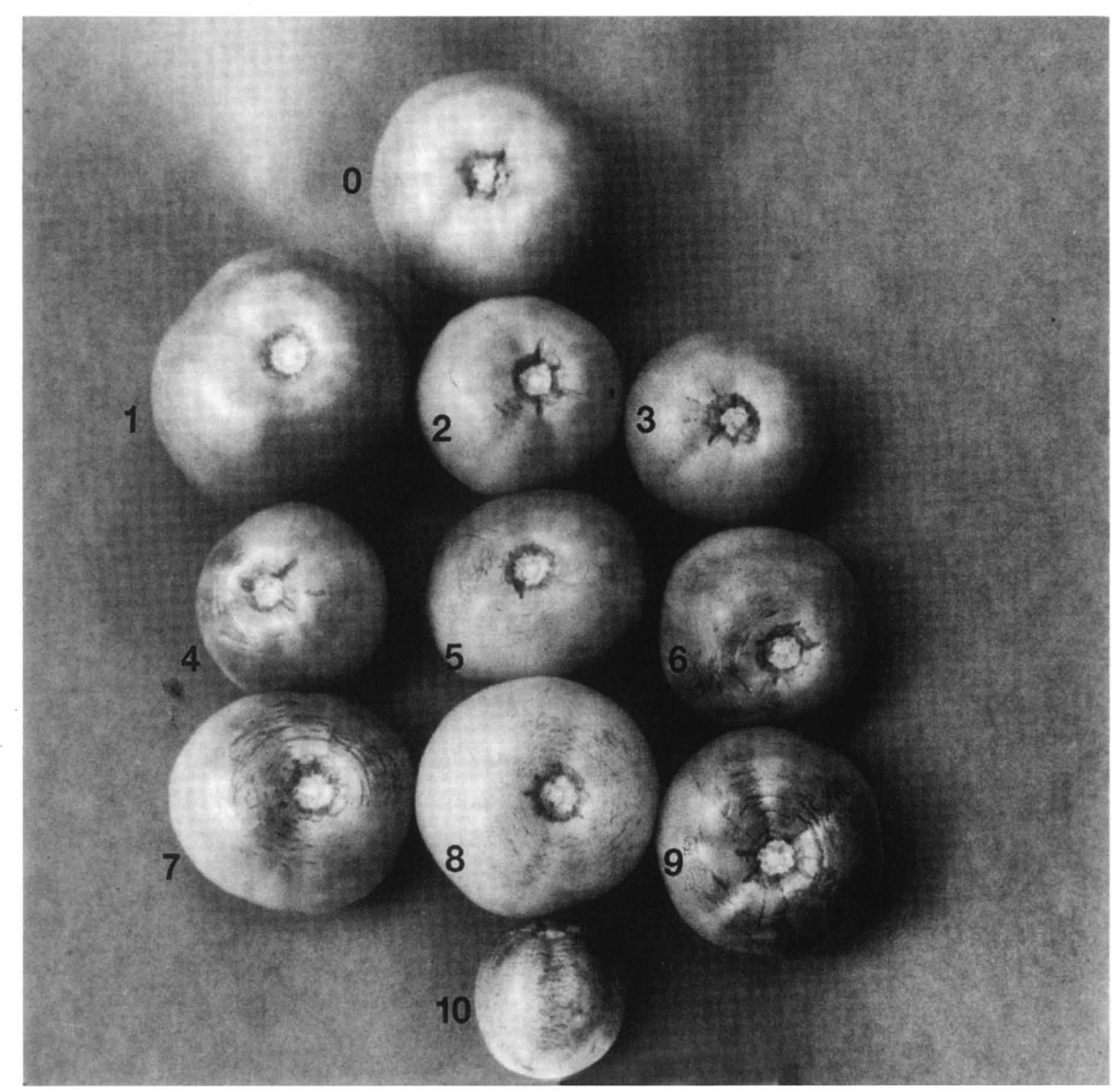


Table 3. Incidence and severity of cuticle cracking in Spring 1992 at Bradenton, Fla.

\begin{tabular}{lcc}
\hline \hline Cultigen & Incidence $^{\mathrm{z}}$ & Severity $^{\mathrm{y}}$ \\
\hline Fla. 7181 & $28.2 \pm 1.8 \mathrm{a}^{\mathrm{x}}$ & $2.6 \pm 0.7 \mathrm{~b}$ \\
Suncoast & $26.6 \pm 2.5 \mathrm{a}$ & $3.0 \pm 1.3 \mathrm{~b}$ \\
NC50-7 & $18.4 \pm 1.5 \mathrm{ab}$ & $3.0 \pm 1.4 \mathrm{~b}$ \\
Fla. 7236 x CL5915 F 3 & $11.5 \pm 1.6 \mathrm{bc}$ & $2.2 \pm 0.9 \mathrm{~b}$ \\
Fla. 7060 & $9.7 \pm 1.2 \mathrm{bc}$ & $2.2 \pm 0.3 \mathrm{~b}$ \\
Solar Set & $6.9 \pm 1.1 \mathrm{~cd}$ & $2.4 \pm 0.5 \mathrm{~b}$ \\
Fla. 7232B x Fla. 7321 F & $5.4 \pm 0.8 \mathrm{~cd}$ & $1.8 \pm 0.6 \mathrm{~b}$ \\
Fla. 7171 & $4.0 \pm 0.5 \mathrm{~cd}$ & $2.7 \pm 1.4 \mathrm{~b}$ \\
C-28 & $2.4 \pm 0.7 \mathrm{~cd}$ & $2.2 \pm 1.8 \mathrm{~b}$ \\
FM-9 & $1.1 \pm 0.3 \mathrm{~d}$ & $3.0 \pm 1.4 \mathrm{~b}$ \\
Fla. 7497 & $0.7 \pm 0.3 \mathrm{~d}$ & $6.0 \pm 0.0 \mathrm{a}$ \\
\hline
\end{tabular}

Percentage of Fruit affected \pm SD.

'Per plant mean \pm sD. See Fig. 1.

'Mean (square root transformed) separation in columns by Duncan's multiple range test at $P \leq 0.05$.

had an effect on CC. A high proportion of rainfall events from planting to harvest occurred within the 2 weeks before harvest. This period coincides with the end of the second growth stage of tomato fruit and the time at which most fruit are harvested. The second growth stage is characterized by rapid cell expansion driven by turgor pressure, leading to increased cell and fruit volume (Rudich and Luchinsky, 1986). Bakker (1988) reported that CC typically occurred 6 to 7 weeks after fruit set (within our 2-week rainfall time frame), and CC severity was significantly correlated with growth rate.

Severity of CC for affected fruit was less sensitive to rainfall patterns than incidence. The tendency was for severity to increase with each harvest, but high variability precluded a significant correlation. Thus, severity was a less reliable indicator of $\mathrm{CC}$ due to environmental conditions than incidence. Furthermore, incidence of CC varied significantly between cultigens. In the 1992 study, cultigens could be distinguished as resistant to $\mathrm{CC}$ when measuring incidence but not when measuring severity. Thus, $\mathrm{CC}$ incidence is a better indicator of susceptibility to $\mathrm{CC}$ and it is simpler and quicker to measure as well.

Until now it was believed that fruit unprotected by leaf cover were more prone to $\mathrm{CC}$ than protected fruit, but there was no data in the literature to support this belief. The fruit exposure experiment reported herein now provides data to support the importance of leaf cover in protecting fruit from $\mathrm{CC}$ damage. Furthermore, staking plants resulted in a significantly lower incidence of CC than allowing plants to grow on the ground. This may relate to an increase in exposure of fruit to the elements for the ground tomatoes. However, removing leaves, fruit, or both (pruning) did not significantly affect the incidence or severity of $\mathrm{CC}$ over all cultigens tested. Pruning had been shown to induce radial and CC in tomatoes (Ehret et al., 1993; Frazier, 1936), but exposing three trusses of tomatoes per plant may not have been extensive enough in our study to attain the same results. Whether the effects of exposure are due to polymerization of cuticular waxes by UV radiation, increased fruit temperature fluctuations, or rain impact is not known.

$\mathrm{CC}$ in tomato was reported to occur at the MG stage of development (den Outer and van Veenendaal, 1987; Young, 1947), although data were not given to support these observations. Our data indicated CC occurred most often at the MG stage, but CC also first appeared during BR and TR stages. As the fruit approach the MG stage and ripening is initiated, the elasticity of the epider- mis decreases (Kamimura et al., 1972). Cultigens most susceptible to cracking were found to be those with low epidermal elasticity (Kamimura et al., 1972). Under moderate water deficit conditions, many tissues will produce more reducing sugars and organic acids to increase the osmotic gradient and maintain turgor (Cosgrove, 1986). If turgor pressure is increased rapidly due to increased uptake of water following a heavy rainfall, $\mathrm{CC}$ could increase. The cells would expand rapidly, placing pressure on the epidermis and cuticle. Limited epidermal elasticity or weaknesses in the cuticular layer would then lead to cracking. Severity of $\mathrm{CC}$ increased by up to 5 rating points, effectively changing from $12.5 \%$ of the fruit shoulder covered with cracks to $100 \%$ of the shoulder affected. Leaving fruit on the plant to ripen beyond MG following a significant rainfall, as would be done in a vine-ripe harvest system, could result in a significant increase in the severity of $\mathrm{CC}$ and, to a lesser extent, the incidence of CC. Harvesting MG fruit and measuring subsequent $\mathrm{CC}$ incidence or severity as fruit ripened off the vine was not tested but would be of interest.

Ehret et al. (1993) found that fruit removal in greenhouse tests resulted in increased CC on remaining fruit compared to fruit from plants with no fruit pruning. Treatments in the field to remove oneto two-thirds of the fruit per plant were performed, but actual fruit load reductions were not that severe due to compensation by the fruit pruned plants where subsequent fruit set and fruit size increased. The incidence and severity of $\mathrm{CC}$ were not significantly affected by the fruit-pruning treatments (data now shown). In field tomatoes, additional fruit removal later in the season would be necessary to attain the desired fruit loads. To do this, it would probably be beneficial to prune sideshoots leaving two stems to control growth and monitor fruit set between treatments.

Our results should be useful to those interested in studying the causes of $\mathrm{CC}$ in tomato and perhaps other crops. A problem in conducting studies on most fruit disorders is to be able to induce the disorder effectively. From our results it is evident that the tomatoes should be grown where rain is expected. Exposing fruit to the elements would also be useful in increasing $\mathrm{CC}$ incidence. Growing plants on the ground probably would increase $\mathrm{CC}$, presumably due to fruit exposure. Leaf removal over fruit trusses could also

Table 4. Pearson correlation coefficients between rainfall at various intervals and cuticle cracking incidence and severity.

\begin{tabular}{llcc}
\hline \hline Interval to harvest & & Incidence $^{\mathrm{z}}$ & Severity $^{\mathrm{y}}$ \\
\hline From transplanting & Amount $(\mathrm{cm})$ & 0.74 & 0.44 \\
& & $(0.15)^{\mathrm{x}}$ & $(0.46)$ \\
& Number of events & 0.91 & 0.46 \\
& & $(0.03)$ & $(0.45)$ \\
$14 \mathrm{~d}$ & Amount $(\mathrm{cm})$ & 0.92 & 0.21 \\
& & $(0.03)$ & $(0.73)$ \\
& Number of events & 0.92 & 0.47 \\
& & $(0.03)$ & $(0.45)$ \\
& & 0.66 & 0.69 \\
& Amount $(\mathrm{cm})$ & $(0.22)$ & $(0.20)$ \\
& & 0.71 & 0.55 \\
& Number of events & $(0.17)$ & $(0.34)$ \\
& & 0.73 & -0.38 \\
& & $(0.16)$ & $(0.53)$ \\
& Amount $(\mathrm{cm})$ & 0.84 & 0.18 \\
& & $(0.07)$ & $(0.74)$ \\
\hline
\end{tabular}

${ }^{2}$ Percentage of fruit affected.

${ }^{y}$ Mean for all affected fruit, ratings based on scale given in Fig. 1.

xparenthetical number indicates the probability that the correlation coefficient above it is nonsignificant. 
Table 5. Incidence of cuticle cracking in staked and not staked plants for three cultigens.

\begin{tabular}{lcc}
\hline Cultigen & Staked & Not staked \\
\hline Fla. 7181 & $12.6 \mathrm{~b}^{\mathrm{z}}$ & $48.5 \mathrm{a}$ \\
Suncoast & $14.0 \mathrm{~b}$ & $44.3 \mathrm{a}$ \\
Fla. 7497 & $4.5 \mathrm{~b}$ & $20.3 \mathrm{a}$ \\
Mean $^{y}$ & $10.4 \mathrm{~b}$ & $38.4 \mathrm{a}$
\end{tabular}

${ }^{\mathrm{x}}$ Mean separation in rows by Duncan's multiple range test at $P \leq 0.05$. Data were transformed to square roots before analysis.

yean for three cultigens.

Table 6. Occurrence of cuticle cracking at different developmental stages of Fla. 7181 tomatoes.

\begin{tabular}{lcc}
\hline \hline Stage & $\begin{array}{c}\text { First appearance of } \\
\text { cuticle cracking } \\
\text { (no. of fruit) }\end{array}$ & $\begin{array}{c}\text { Fruit with } \\
\text { cuticle cracking } \\
(\%)\end{array}$ \\
\hline Immature green & 1 & 2 \\
Mature green & 38 & 61 \\
Breaker & 17 & 27 \\
Red & 6 & 10 \\
\hline
\end{tabular}

${ }^{\mathrm{z}}$ From a total of 62 fruit.

Table 7. Timing of increase of severity of cuticle cracking after initial occurrence in Fla. 7181 tomatoes.

\begin{tabular}{lcrr}
\hline & Fruit & \multicolumn{2}{c}{$\begin{array}{c}\text { Fruit with } \\
\text { increased severity }\end{array}$} \\
\cline { 3 - 4 } Stage $^{\mathrm{z}}$ & (no.) & (no.) & $(\%)$ \\
\hline IG to MG & 1 & 0 & 0 \\
MG to BR & 37 & 27 & 73 \\
BR to TR & 67 & 15 & 22 \\
\hline
\end{tabular}

$\overline{{ }_{\mathrm{IG}}}=$ immature-green; $\mathrm{MG}=$ mature-green; $\overline{\mathrm{BR}}=$ breaker; $\mathrm{TR}=$ table-ripe.

increase $\mathrm{CC}$, but this treatment did not increase $\mathrm{CC}$ in staked tomato plants tested here. It is evident that $\mathrm{CC}$ incidence can be increased, but due to interaction with environmental conditions the incidence of this disorder can not be easily predicted.

Growers, on the other hand, would want to minimize $\mathrm{CC}$ by harvesting before rains if possible and using practices that minimize fruit exposure. This would include staking plants, preventing foliar diseases, and using care in harvesting not to damage foliage that would protect fruit to be harvested later. Certainly choosing cultivars with resistance to $\mathrm{CC}$ is an important consideration, especially if harvesting fruit riper than MG. In evaluating cultivars, one should monitor $\mathrm{CC}$ incidence since this related to resistance much better than $\mathrm{CC}$ severity. Even the most resistant cultivars will have some percentage of severely affected fruit under conditions conducive to the disorder.

\section{Literature Cited}

Bakker, J.C. 1988. Russeting (cuticle cracking) in glasshouse tomatoes in relation to fruit growth. J. Hort. Sci. $63: 459-463$.

Cosgrove, D. 1986. Biophysical control of plant cell growth. Annu. Rev. Plant Physiol. 37:377-405.

den Outer, R.W. and W.L.H. van Veenendaal, 1987. Anatomical investigation of tomatoes with swelling cracks. Groeten en Fruit 42(46):40-42.

Ehret, D.L., T. Helmer, and J.W. Hall. 1993. Cuticle cracking in tomato fruit. J. Hort. Sci. 68:195-201.

Faust, M. and C.B. Shear. 1972. Russeting of apples, an interpretative review. HortScience 7:233-235.

Frazier, W.A. 1936. Further studies on the occurrence of cracks in tomato fruits. Proc. Amer. Soc. Hort. Sci. 33:536-541.

Hayman, G. 1987. The hair-like cracking of last season. Grower 107:35.

Hochmuth, G.J., D.N. Maynard, and M. Sherman. 1989. Tomato production guide for Florida. Fla. Coop. Ext. Circ. 98C:4-11.

Kamimura, S., H. Yoshhikawa, and K. Ito. 1972. Studies on fruit cracking in tomatoes. Bul. Hort. Res. Sta. Morioka, Iwate, Japan 7:7-138.

Reynard, G.B. 1951. Inherited resistance to radial cracks in tomato fruits. J. Amer. Soc. Hort. Sci. 58:231-244.

Rudich, J. and U. Luchinsky. 1986. Water economy. In: J.G. Atherton and J. Rudich (eds.). The tomato crop. A scientific basis for improvement. Chapman and Hall Ltd., Cambridge.

Soule, J. 1985. Glossary for horticultural crops. Wiley, New York.

Tukey, L.D. 1959. Observations on the russeting of apples grown in plastic bags. Proc. Amer. Soc. Hort. Sci. 74:30-39.

Vincent, C.L. and A. Malenaar. 1951. Studies in sprinkler irrigation with Stokesdale tomatoes. Proc. Amer. Soc. Hort. Sci. 57:259-265.

Vries, H.A. 1970. Polymerization of the cutin acids of the apple skin. Acta Bot. Nederl. 19:41-48.

Wehner, T.C. , P.C. St. Armand, and R.L. Lower. 1996. 'M 17' gummy stem blight resistant pickling cucumber inbred. HortScience 31:1248 1249.

Young, P.A. 1947. Cuticle cracks in tomato fruits. Phytopathology 37:143-145.

Zar, J.H. 1984. Biostatistical analysis. Prentice-Hall. Englewood Cliffs, N.J. 